\title{
PENERAPAN METODE PEMBELAJARAN TUTOR SEBAYA UNTUK MENINGKATKAN AKTIVITAS DAN HASIL BELAJAR SISWA DI SMA NEGERI 9 PONTIANAK
}

\author{
Diana Rosanti \\ SMA Negeri 9 Pontianak \\ Email : dianarosanti77@gmail.com \\ DOI: 10.26418/jpmipa.v9i2.26773
}

\begin{abstract}
This study aims to determine the improvement of student activity and learning outcomes in the system of linier equations of three variables using peer tutoring methods. Form of research is classroom action research consists of two cycles. Each cycle stage consists of planning, implementation, observation and reflection. Data collection was obtained by direct observation and test. Subject are students of class $X$ (Sosial science)1 SMAN 9 Pontianak. Based on the results of research, it can be concluded that learning by peer tutoring methods can improve the activity and learning outcomes of students. This is marked by the increase of student activity average starting from cycle I of 2.96 (good category) to 3.51 (very good category) in cycle II with percentage increase of $58.33 \%$. There is an increase because the tutor understands the material and has a good emotional level towards his friend. In line with the ability possessed by the tutor and the ability of the teacher in managing the learning, there is a significant increase of the test results given. At the pre cycle the percentage of students' completeness of $26.32 \%$ increased by $28.95 \%$ to $55.26 \%$ in cycle I. Similarly in cycle II there was an increase in learning outcomes by $31.58 \%$ from $55.25 \%$ in cycle I to $86.84 \%$ in cycle II. In accordance with the research indicator that the success of this study is seen from $80 \%$ of students complete with minimal standart is 75 , so this research is said to be successful and stopped in cycle II.

Keywords : Peer Tutoring Methods, Activity, Learning Outcomes
\end{abstract}

Pendidikan matematika di sekolah saat ini sedang mengalami perubahan paradigma. Pemerintah memberikan perhatian lebih terhadap pembelajaran matematika sekolah, hal ini dapat dilihat dari penambahan jam pelajaran matematika dalam Kurikulum 2013 sesuai dengan Permendikbud No 69 tahun 2013 tentang kerangka dasar dan struktur kurikulum Sekolah Menengah Atas
/Madrasah Aliyah. Bertambahnya jumlah jam pelajaran matematika tersebut diharapkan dapat memenuhi kebutuhan masa kini dan masa yang akan datang. Sejalan dengan karakteristik matematika yang dikemukakan oleh Soemarmo (2014:6) bahwa visi pertama pembelajaran matematika adalah mengarahkan pembelajaran matematika untuk pemahaman 
konsep dan ide matematika yang dapat digunakan untuk menyelesaikan masalah matematika dan ilmu pengetahuan lainnya. Visi kedua lebih mengarah ke masa depan, dimana matematika mampu memberikan peluang untuk mengembangkan nalar sehingga dapat berpikir secara logis, sistematik, kritis, cermat, kreatif, dan menimbulkan rasa keindahan terhadap keteraturan sifat matematika, serta mengembangkan sikap objektif dan terbuka yang sangat diperlukan dalam menghadapi masa depan yang selalu berubah.

Sebagai ujung tombak pelaksana di sekolah guru hendaknya menyadari fungsi sebagai fasilitator bagi siswa karena pembelajaran yang diharapkan tidak lagi berpusat pada guru (teacher centered) melainkan berpusat kepada siswa (student centered). Guru harus merubah perannya, tidak lagi sebagai pemegang otoritas tertinggi keilmuan dan indoktriner, tetapi menjadi fasilitator yang membimbing siswa ke arah pembentukan pengetahuan oleh diri sendiri. Seperti yang dikemukakan oleh Zulkadri (dalam Soemarmo, 2014:8) bahwa melalui paradigma baru dalam pembelajaran matematika diharapkan siswa menjadi aktif dalam belajar, aktif berdiskusi, berani menyampaikan gagasan dan menerima gagasan orang lain, dan memiliki kepercayaan diri yang tinggi.

Banyak cara yang dapat dilakukan guru sebagai fasilitator dalam pembelajaran diantaranya melalui berbagai alternatif pendekatan, mulai dari pemilihan strategi pembelajaran sampai penggunaan alat peraga. Guru sebagai fasilitator dalam belajar artinya guru mampu menyediakan situasi atau suasana pembelajaran agar pembelajaran berlangsung dengan baik (Uno \& Mohamad, 2011:15). Hal ini di dukung oleh Permendikbud No. 65 tahun 2013 bahwa proses pembelajaran pada satuan pendidikan diselenggarakan secara interaktif, inspiratif, menyenangkan, menantang, memotivasi siswa untuk berpartisipasi aktif, serta memberikan ruang yang cukup bagi prakarsa, kreativitas dan kemandirian sesuai bakat, minat dan perkembangan fisik serta psikologis siswa.

Muara dari semua strategi yang digunakan dalam pembelajaran adalah bagaimana proses pembelajaran itu berjalan dengan baik dan menarik bagi siswa yang belajar. Siswa harus didorong untuk berpikir, menganalisa, membentuk opini, praktik dan mengaplikasikan pembelajaran mereka dan bukan hanya menjadi pendengar pasif atas apa yang disampaikan guru. Agar siswa dapat aktif dalam proses pembelajaran guru sebagai fasilitator hendaknya menyediakan pengalaman belajar yang dapat membantu siswa mengembangkan seluruh potensi dirinya, siswa dapat membangun pengetahuannya melalui kerjasama dengan teman sebayanya melalui bimbingan guru (Mujiarso, 2014:110). Dalam hal ini, guru memfasilitasi siswanya untuk dapat melibatkan pembelajaran bersama ataupun berbentuk grup belajar untuk mendorong antar siswa berinteraksi. Menurut Siregar \& Nara (2010:106) pembelajaran aktif (active learning) dimaksudkan untuk mengoptimalkan penggunaan semua potensi yang dimiliki oleh siswa sehingga semua 
siswa dapat mencapai hasil belajar yang memuaskan sesuai dengan karakteristik pribadi yang mereka miliki.

Berdasarkan pengalaman dalam mengajar matematika di SMA Negeri 9 Pontianak, guru sering kali menghadapi masalah dalam pembelajaran diantaranya siswa cenderung pasif dalam mengemukakan pendapat dan hasil belajar siswa yang masih rendah. Dari hasil pengamatan yang dilakukan guru pada saat pembelajaran, dari 38 orang siswa yang terlibat aktif dalam pembelajaran kurang dari $20 \%$ (6-8 orang). Demikian juga saat diberikan tes hasil belajar, siswa yang tuntas hanya 10 orang (prosentase ketuntasan 26,32\%).

Untuk mengatasi masalah dalam pembelajaran, guru melakukan wawancara terhadap 5 orang siswa yang mewakili nilai tidak tuntas dan cenderung pasif dalam pembelajaran. Dari hasil wawancara diketahui bahwa siswa cenderung merasa takut dan malu untuk mengemukakan pendapat kepada guru saat proses pembelajaran berlangsung. Selain itu, siswa juga mengalami kesulitan dalam membuat kalimat pertanyaan untuk mengungkap masalah yang mereka alami. Siswa merasa lebih berani bertanya dan mengemukakan pendapatnya pada teman atau siswa yang lain, namun itupun hanya pada siswa tertentu yang mereka anggap mau berbagi ilmu. Untuk itu guru berinisiatif mencoba menerapkan metode pembelajaran dengan tutor sebaya (peer teaching).

Pemilihan metode pembelajaran tutor sebaya merupakan salah satu alternatif yang dapat diterapkan kepada siswa dalam proses pembelajaran yang dilakukan dengan kelompok kecil. Tujuan dari proses pembelajaran dengan kelompok adalah : 1) meningkatkan partisipasi optimal siswa dalam belajar, 2) memberi pelajaran kepemimpinan dan pengalaman membuat keputusan kelompok, 3) memberi kesempatan untuk berinteraksi dan belajar dengan siswa lain yang berasal dari latar belakang budaya (kebiasaan) dan kemampuan yang berbeda (Kosasih, 2014:101). Dengan metode pembelajaran secara berkelompok yang di pimpin oleh seorang tutor diharapkan siswa memiliki kemampuan yang lebih baik secara kognitif (pengetahuan) dan keterampilan. Hal ini sejalan dengan pendapat Hanik \& Harsono (2016:2531) bahwa dengan pendekatan kooperatif (kelompok) dapat mendorong dan memberi kesempatan siswa untuk terampil berkomunikasi dan membentuk konsep baru bersama temannya maka akan terjadi peningkatan aktivitas dan hasil belajar.

Beberapa pendapat yang mendukung dalam pembelajaran dengan metode tutor sebaya yaitu Arjanggi (2010: 91-97) bahwa metode tutor sebaya adalah suatu metode pembelajaran yang dilakukan dengan cara memberdayakan siswa yang memiliki daya serap yang tinggi dari kelompok siswa itu sendiri untuk menjadi tutor bagi teman-temannya, dimana siswa yang menjadi tutor bertugas untuk memberikan materi belajar dan latihan kepada temantemannya (tutee) yang belum paham terhadap materi/latihan yang diberikan guru dengan dilandasi aturan yang telah disepakati bersama dalam kelompok tersebut sehingga 
akan terbangunsuasana belajar kelompok yang bersifat kooperatif bukan kompetitif.

Djamarah (2015:26) juga mengemukakan beberapa manfaat dari pembelajaran dengan metode tutor sebaya, antara lain : 1) hasilnya lebih baik bagi beberapa anak yang memiliki perasaan takut atau enggan kepada guru, 2) bagi tutor, dapat memberikan kesempatan untuk menelaah kembali secara mendalam dan melatih diri untuk mengemban tanggung jawab dan kesabaran, 3) mempererat hubungan sosial antara siswa. Sejalan dengan hal ini, Anggorowati (2011:104) juga mengungkapkan beberapa kelebihan dalam penggunaan metode tutor sebaya antara lain : 1) melatih siswa agar dapat membiasakan diri untuk mengeluarkan pendapat dan berkomunikasi dengan orang lain, dalam hal ini teman sejawat dan guru, 2) melatih kemampuan siswa untuk berinisiatif dan kreatif dalam melakukan suatu hal baru terutama dalam menangani suatu masalah, 3) melatih kemampuan siswa untuk bekerja sama dengan teman sejawat dengan semangat kebersamaan dan berbagi pengetahuan.

Berdasarkan pendapat tokohtokoh tersebut diatas, guru berpendapat dengan metode pembelajaran tutor sebaya diharapkan siswa lebih mudah berinteraksi dan berkomunikasi dengan sesama teman sehingga dapat lebih memahami materi yang diberikan. Siswa yang menjadi tutor hendaknya mempunyai kemampuan akademik yang lebih tinggi dibandingkan dengan teman lainnya, sehingga pada saat dia memberikan bimbingan dia sudah menguasai bahan yang akan disampaikan (Huda, 2009:28). Namun pengalaman guru selama mengajar, terkadang siswa yang memiliki kemampuan tinggi tidak mampu untuk menyampaikan kembali materi kepada temantemannya. Untuk itu dilakukan beberapa pertimbangan dalam pemilihan tutor.

Djamarah

mengemukakan bahwa beberapa kriteria dalam menentukan seorang tutor sebaya antara lain: 1) dapat diterima (disetujui) siswa yang menjadi anggota kelompok sehingga tidak mempunyai rasa takut atau enggan untuk bertanya kepada tutor, 2) dapat menerangkan kembali materi yang diperlukan oleh anggota kelompoknya, 3) tidak tinggi hati, kejam dan keras hati sesama kawan, 4) mempunyai daya kreatifitas yang cukup untuk memberikan bimbingan, yaitu dapat menerangkan pelajaran kepada temannya. Dalam penelitian ini, tutor sebaya dipilih berdasarkan pengamatan dan penilaian guru terhadap kemampuan pengetahuan, ketrampilan dan sikap siswa selama pembelajaran pada materi-materi sebelumnya serta berdasarkan hasil pre-tes materi yang akan dipilih dalam penelitian.

Agar lebih maksimal hasil yang diperoleh maka materi yang dipilih sebaiknya merupakan materi yang sudah dikuasai oleh tutor sebaya sehingga tutor sebaya dapat menyampaikan materi tersebut kepada teman-temannya dengan baik. Dalam penelitian ini materi yang diambil adalah Sistem Persamaaan Linier Tiga Variabel (SPLTV) merupakan materi wajib pada kelas $\mathrm{X}$ dalam kurikulum 2013. Pertimbangan guru bahwa materi SPLTV 
merupakan materi lanjutan dari SPLDV (Sistem Persamaan Linier Dua Variabel) yang telah siswa pelajari di Sekolah Menengah Pertama (SMP) sehingga tutor sudah memiliki kemampuan prasyarat yang cukup untuk memenuhi kriteria sebagai tutor. Sebelum pelaksanaan penelitian guru juga memberikan matrikulasi kepada tutor agar lebih memahami dan dapat menyampaikan materi SPLTV dengan baik kepada anggota kelompok masing-masing.

\section{METODE}

Sasaran penelitian ini adalah siswa kelas X Ilmu-Ilmu Sosial (IIS) 1 di SMA Negeri 9 Pontianak yang berjumlah 38 orang siswa, terdiri dari 12 siswa laki-laki dan 26 siswa perempuan. Pemilihan kelas X IIS 1 karena aktivitas siswa dalam pembelajaran masih kurang dan hanya beberapa siswa yang terlibat aktif dalam pembelajaran. Selain itu hasil belajar siswa pada pre-tes materi SPLDV masih sangat rendah.

Penelitian ini merupakan penelitian tindakan kelas (PTK). Menurut Suyadi (2010:21) bahwa PTK adalah tindakan-tindakan yang diambil guru dalam rangka meningkatkan kemampuan siswa dilihat dari kelemahan dan kelebihan pola pembelajaran melalui diagnosis proses belajar dan hasil belajar siswa selama berlangsungnya proses pembelajaran. Arikunto (dalam Suyadi 2010:49) mengemukakan bahwa penelitian tindakan kelas terdiri dari empat kegiatan yang dilakukan dalam siklus yang berulang. Empat kegiatan utama yang ada pada setiap siklus yaitu perencanaan (planning), pelaksanaan (acting), pengamatan (observing) dan refleksi (reflecting).

Instrumen yang digunakan dalam penelitian ini adalah : 1) Lembar observasi kegiatan guru dalam pembelajaran, 2) Lembar observasi aktivitas siswa dalam pembelajaran, dan 3) Tes tertulis berupa tes akhir pada setiap siklus (Siklus I dan Siklus II). Data yang diperoleh bersifat kuantitatif berupa skor terhadap aktivitas guru dan siswa dalam pembelajarandan skor dari tes akhir pada setiap siklus. Observasi yang dilakukan dalam penelitian ini adalah observasi terstruktur yaitu observasi yang telah dirancang secara sistematis tentang apa yang akan diamati, kapan dan dimana tempatnya (Sugiyono, 2014:205). Data hasil observasi diolah dengan mencari jumlah rata-rata dan persentase dari penilaian observer selama pembelajaran. Aktivitas siswa dinilai sangat baik bila memperoleh hasil konversi skor pada interval dengan nilai A. Interpretasi skor dalam penelitian ini dikutip dari Melati (2015:51).

Selain observasi terhadap aktivitas siswa juga dilakukan observasi terhadap kemampuan guru dalam mengelola pembelajaran. Observasi kemampuan guru mengelola pembelajaran dilakukan berdasarkan pada setiap aspek dengan mengacu pada poin-poin yang terdapat pada Rencana Pelaksanaan Pembelajaran (RPP) yang telah disusun. Penskoran pada lembar observasi dinyatakan dalam skala Likert yaitu 1 (sangat tidak setuju), 2 (tidak setuju), 3 (setuju) dan 4 (sangat setuju). 
Tabel 1. Interpretasi skor aktivitas siswa dalam pembelajaran.

\begin{tabular}{ccc}
\hline Nilai & Interval skor & Kategori \\
\hline $\mathrm{A}$ & $\left(\bar{x}_{\mathrm{i}}+1,80 \mathrm{SB}_{\mathrm{i}}\right)<\bar{x}$ & Sangat Baik \\
\hline $\mathrm{B}$ & $\left(\bar{x}_{\mathrm{i}}+0,60 \mathrm{SB}_{\mathrm{i}}\right)<\bar{x} \leq\left(\bar{x}_{\mathrm{i}}+1,80 \mathrm{SB}_{\mathrm{i}}\right)$ & Baik \\
\hline $\mathrm{C}$ & $\left.\overline{(x}_{\mathrm{i}-}-0,60 \mathrm{SB}_{\mathrm{i}}\right)<\bar{x} \leq\left(\bar{x}_{\mathrm{i}}+0,60 \mathrm{SB}_{\mathrm{i}}\right)$ & Cukup \\
\hline $\mathrm{D}$ & $\left(\bar{x}_{\mathrm{i}-}-1,80 \mathrm{SB}_{\mathrm{i}}\right)<\bar{x} \leq\left(\bar{x}_{\mathrm{i}-}-0,60 \mathrm{SB}_{\mathrm{i}}\right)$ & Kurang \\
\hline $\mathrm{E}$ & $\bar{x} \leq\left(\bar{x}_{\mathrm{i}}-1,80 \mathrm{SB}_{\mathrm{i}}\right)$ & Sangat Kurang \\
\hline
\end{tabular}

Keterangan :

$\bar{x}_{\mathrm{i}}=$ rerata skor ideal

$=1 / 2 \quad$ (skor maksimal+skor minimal)

Tabel 1 dengan indikator kemampuan guru mengelola pembelajaran dianggap baik jika hasil konversi menunjukkan rentang nilai pada kategori minimal B.

$=1 / 6$ (skor maksimal + skor minimal)

$\bar{x}=$ skor aktual

Persentase pada aktivitas ini dihitung dengan :

$\mathrm{P}=\frac{Q}{R} \times 100 \%$

Keterangan :

$\mathrm{P}=$ persentase

$\mathrm{Q}=$ skor yang diperoleh pada aspek aktivitas

$\mathrm{R}=$ skor maksimum pada aspek yang dinilai yaitu 4

Adapun pendeskripsian skor rata-rata tingkat kemampuan guru dalam mengelola pembelajaran mengacu

\section{HASIL DAN PEMBAHASAN}

Penelitian tindakan kelas ini terdiri dari beberapa tahap yaitu pra siklus, siklus I dan siklus II. Untuk mengetahui kemampuan siswa pada materi prasyarat yaitu SPLDV, peneliti memberikan pre-tes. Nilai pre-tes selanjutnya digunakan sebagai pedoman untuk menentukan pembagian kelompok dan sebagai salah satu kriteria pemilihan tutor sebaya untuk tiap kelompok. Berikut ini hasil dari pre- tes pada tahap pra siklus.

pada tabel konversi nilai yang dikutip dari Melati (2015:51) seperti pada

Tabel 2. Hasil pre-tes siswa pada tahap pra siklus

\begin{tabular}{|c|c|c|c|}
\hline \multirow{2}{*}{ Rentang Nilai } & \multirow{2}{*}{ Kategori } & \multicolumn{2}{|c|}{ Pra Siklus } \\
\hline & & Siswa & $\%$ \\
\hline $90-100$ & Sangat Baik & 5 & 13,16 \\
\hline $70-89$ & Baik & 6 & 15,79 \\
\hline $50-69$ & Cukup & 17 & 44,74 \\
\hline $30-49$ & Kurang & 10 & 26,32 \\
\hline $10-29$ & Sangat Kurang & 0 & 0,00 \\
\hline \multicolumn{2}{|c|}{ Jumlah } & 38 & 100 \\
\hline
\end{tabular}

Sumber : Data Primer, diolah November 2016 
Berdasarkan nilai tes awal pada tahap pra siklus bahwa ketuntasan belajar siswa hanya mencapai $26 \%$ (10 orang) dan siswa tidak tuntas sebanyak $74 \%$ (28 orang) dengan standar ketuntasan minimal 75. Selanjutnyaberdasarkan hasil pre-tes dilakukan pemilihan kelompok yang terdiri dari 5-6 orang siswa termasuk tutor sebaya. Kelompok dipilih secara heterogen baik dari segi kemampuan dan jenis kelamin. Pada tahap kegiatan pembelajaran siklus I dan siklus II disajikan pada Tabel 3.

Tabel 3. Analisis kegiatan pembelajaran yang dilakukan guru

\begin{tabular}{lcccc}
\hline \multirow{2}{*}{ Deskripsi } & \multicolumn{2}{c}{ Siklus I } & \multicolumn{2}{c}{ Siklus II } \\
\cline { 2 - 5 } & $\begin{array}{c}\text { Pertemuan } \\
\text { I }\end{array}$ & $\begin{array}{c}\text { Pertemuan } \\
\text { II }\end{array}$ & $\begin{array}{c}\text { Pertemuan } \\
\text { I }\end{array}$ & $\begin{array}{c}\text { Pertemuan } \\
\text { II }\end{array}$ \\
\hline Terlaksana (\%) & $66,67 \%$ & $93,33 \%$ & $100 \%$ & $100 \%$ \\
\hline $\begin{array}{l}\text { Tidak } \\
\text { Terlaksana (\%) }\end{array}$ & $33,33 \%$ & $6,67 \%$ & $0 \%$ & $0 \%$ \\
\hline
\end{tabular}

Sumber : Data Primer, diolah November 2016

Berdasarkan Tabel 3 , tampak
bahwa pelaksanaan pembelajaran yang dilakukan guru pada siklus I pertemuan I sebesar $66,67 \%$ mengalami peningkatan pada pertemuan II sebesar 93,33\%, namun masih ada kekurangan yang perlu diperbaiki yaitu pada kegiatan memberi penguatan kepada siswa yang menjawab benar dan memberikan bimbingan/arahan kepada siswa yang belum menjawab dengan benar. Belum tercapainya hasil yang memuaskan disebabkan guru tidak melaksanakan pembelajaran sesuai dengan alokasi waktu yang telah ditentukan. Guru lebih banyak menghabiskan waktu pada kegiatan pendahuluan yaitu mempersiapkan siswa dalam kelompok dan memberikan arahan terkait metode pembelajaran dengan tutor sebaya. Selain itu pada saat diskusi kelompok berlangsung guru belum memberikan bimbingan kepada kelompok yang anggotanya kurang aktif sehingga tutor mengalami kendala dalam menjelaskan materi kepada beberapa anggota kelompoknya sehingga memakan waktu lebih lama. Sedangkan pada siklus 2 baik pada pertemuan 1 dan pertemuan II guru sudah melaksanakan semua tahapan sesuai dengan rencana pelaksanaan pembelajaran yang telah dibuat.

Aktivitas siswa pada siklus I dan siklus II juga mengalami peningkatan seperti yang disajikan dalam Tabel 4. Dari Tabel 4 tampak bahwa terjadi peningkatan rata-rata skor keseluruhan aktivitas siswa pada siklus I sebesar 2,96 menjadi 3,51 pada siklus II dengan prosentase peningkatan sebesar $58,33 \%$. Terjadi peningkatan yang signifikan setelah guru mempersiapkan siswa dengan baik dimulai dari membuat susana kelas menjadi menyenangkan dengan penampilan yel-yel pada awal pembelajaran. Selain itu yang lebih utama adanya penguatan dari guru terhadap siswa yang kurang aktif berpartisipasi dalam diskusi kelompok, sehingga tutor menjadi lebih mudah dalam menjelaskan materi kepada anggota kelompoknya. 
Tabel 4. Hasil interpretasi skor aktivitas siswa pada siklus I dan siklus II

\begin{tabular}{ccccc}
\hline \multirow{2}{*}{ No } & Siklus & Pertemuan I & Pertemuan II & $\begin{array}{c}\text { Rata-rata } \\
\text { Tiap } \\
\text { siklus }\end{array}$ \\
\cline { 3 - 5 } 1 & Siklus I & 2,80 & 3,12 & 2,96 \\
\hline 2 & Siklus II & 3,25 & 3,77 & 3,51 \\
\hline
\end{tabular}

Sumber : Data Primer, diolah November 2016

Mengingat pentingnya peran tutor dalam pembelajaran dengan metode tutor sebaya sebaiknya selain tutor merupakan siswa yang memiliki pemahaman lebih baik terhadap materi juga siswa yang memiliki kemampuan baik dalam berkomunikasi, memiliki hubungan emosional yang baik dengan teman, bersahabat dan bertanggung jawab dalam melaksanakan tugas yang diberikan. Peningkatan hasil belajar pada pra siklus, siklus I dan siklus II disajikan dalam Tabel 5.

Tabel 5. Rekapitulasi hasil belajar siswa pada pra siklus, siklus I dan siklus II.

\begin{tabular}{lccc}
\hline \multirow{2}{*}{ Keterangan Nilai } & \multicolumn{3}{c}{ Hasil Belajar } \\
\cline { 2 - 4 } & Pra Siklus & Siklus I & Siklus II \\
\hline Nilai Tertinggi & 100 & 100 & 100 \\
\hline Nilai Terendah & 35 & 40 & 60 \\
\hline Rata-rata & 62,24 & 70,00 & 85,26 \\
\hline Jumlah siswa tuntas & 10 & 21 & 33 \\
\hline Jumlah siswa tidak tuntas & 28 & 17 & 5 \\
\hline Jumlah siswa keseluruhan & 38 & 38 & 38 \\
\hline Prosentase ketuntasan & 26,32 & 55,26 & 86,84 \\
\hline
\end{tabular}

Sumber : Data Primer, diolah November 2016

Berdasarkan rekapitulasi nilai pada Tabel 5 dapat diketahui bahwa nilai rata-rata kelas pada pra siklus sebesar 62,24 dan ketuntasan belajar $26,32 \%$ belum memenuhi indikator keberhasilan. Indikator keberhasilan untuk tes hasil belajar siswa sebesar $80 \%$ siswa tuntas dengan kriteria ketuntasan 75. Pada siklus I diperoleh

Berdasarkan hasil penelitian yang disajikan pada Tabel 4 terjadi peningkatan rata-rata aktivitas siswa pada setiap siklus dengan prosentase rata-rata peningkatan $58,33 \%$. prosentase ketuntasan siswa sebesar $55,26 \%$ dan belum memenuhi indikator keberhasilan, maka diadakan perbaikan pada siklus II sehingga mencapai prosentase ketuntasan sebesar $86,84 \%$ sudah memenuhi indikator keberhasilan sehingga penelitian ini dikatakan berhasil dan dihentikan pada siklus II. Peningkatan aktivitas siswa karena ada sedikit modifikasi dalam langkahlangkah pembelajaran yaitu guru mengarahkan siswa yang awalnya pasif untuk aktif bertanya dan 
berpartisipasi dalam diskusi. Hasil belajar siswa juga mengalami peningkatan yang cukup signifikan pada tiap siklus dan pada siklus II mencapai $86,84 \%$ siswa tuntas seperti yang disajikan pada Tabel 5. Hal ini memenuhi indikator keberhasilan hasil tes belajar sebesar $80 \%$ siswa tuntas dengan kriteria ketuntasan 75 sehingga penelitian ini dikatakan berhasil dan dihentikan pada siklus II.

Pembelajaran dengan tutor sebaya mampu mengatasi kesenjangan antara siswa yang memiliki kemampuan tinggi dan siswa yang memiliki kemampuan rendah. Tutor berperan dalam membantu temannya dalam memahami materi pembelajaran. Metode tutor sebaya dapat terlaksana dengan baik dan mencapai tujuan pembelajaran tergantung dari siswa yang menjadi tutor. Untuk itu, kriteria dalam pemilihan tutor hendaknya dipenuhi terutama terkait dengan kemampuan akademis diatas rata-rata dan mampu berkomunikasi dengan baik kepada teman-temannya dalam menyampaikan materi.

Untuk dapat mempertahankan keakraban dan rasa memiliki di dalam kelompok maka perlu diperhatikan jumlah anggota kelompok tersebut. Langkah-langkah yang digunakan dalam penelitian sebagai berikut : 1) memilih tutor sebaya untuk tiap kelompok dengan syarat tutor memiliki kemampuan akademis tinggi dibanding anggota kelompoknya berdasarkan nilai evaluasi sebelumnya dan memiliki kemampuan komunikasi yang baik dalam menyampaikan ide-idenya berdasarkan beberapa kali pengamatan guru pada pembelajaran sebelumnya, 2) mengelompokkan siswa secara heterogen yaitu siswa dalam satu kelompok memiliki kemampuan tinggi, sedang dan rendah. Selain itu mempertimbangkan komposisi jenis kelamin dalam tiap kelompok sehingga siswa merasa semua diperlakukan sama baik lakilaki maupun perempuan, 3) sebelum pelaksanaan pembelajaran dengan metode tutor sebaya sebaiknya guru menyampaikan beberapa penjelasan terkait materi dan mempersiapkan materi berupa lembar kerja siswa yang memadai agar siswa mudah memahami materi, 3) pada saat pelaksanaan guru menyiapkan lembar observasi untuk memberikan penilaian dan melakukan refleksi kegiatan.

\section{KESIMPULAN DAN SARAN}

Kesimpulan yang diperoleh dari hasil penelitian adalah pembelajaran dengan metode tutor sebaya dapat meningkatkan aktivitas siswa sebesar $58,33 \%$ yakni dari siklus I sebesar 2,96 (kategori baik) menjadi 3,51 (kategori sangat baik) pada siklus II. Peningkatan yang cukup signifikan juga dilihat dari prosentase ketuntasan siswa pada tes hasil belajar yaitu siklus I sebesar 55,26\% dan siklus II sebesar $86,84 \%$. Terjadi peningkatan prosentase ketuntasan dari siklus I ke siklus II sebesar $31,58 \%$. Sesuai dengan indikator penelitian bahwa keberhasilan penelitian ini dilihat dari minimal $80 \%$ siswa tuntas dengan nilai KKM 75, sehingga penelitian ini dikatakan berhasil dan dihentikan pada siklus II.

Perlu adanya perbaikan dalam penelitian diantaranya dalam penerapan metode pembelajaran tutor sebaya dengan memperhatikan komposisi dari pembagian aggota 
kelompok sehingga mempermudah tutor dalam menjelaskan materi kepada anggota kelompok, mengingat metode tutor sebaya membutuhkan pemahaman lebih dari tutor untuk menjelaskan kepada temannya maka sebaiknya dipilih materi yang sudah pernah mereka dapatkan sebelumnya,

\section{DAFTAR PUSTAKA}

Anggorowati, P. Ningrum. (2011). Penerapan Model Pembelajaran Tutor Sebaya pada Mata Pelajaran Sosiologi. Semarang. Jurnal Komunitas Universitas Negeri Semarang.

Arjanggi. R dan Suprihatin T. (2010). Metode Pembelajaran Tutor Teman Sebaya Meningkatkan Hasil Belajar Berdasarkan Regulasi Diri. Jurnal Universitas Indosnesi. [online].

Djamarah, S.B. \& Zain, A. ( 2015). Strategi Belajar Mengajar. Jakarta. Rineka Cipta.

Hanik, N. R \& Harsono, S. (2016). Peningkatan aktivitas dan Hasil Belajar Mahasiswa pada Mata Kuliah Anatomi Tumbuhan Melalui Model Pembelajaran Komparasi yang Berbasis Lesson Study. Jurnal Pendidikan Matematika dan IPA, Vol 7, N0 2, 25-31.

Huda, A.Q. (2009). Penerapan Model Pembelajaran Cooperative Learning Tipe Peer Tutoring (Tutor Sebaya) untuk Meningkatkan Hasil Belajar IPS Kompetensi Dasar Hidrosfer Siswa Kelas VII SMPN 07 Kota Semarang Tahun Ajaran 2008/2009. Skripsi. Semarang: FIS UNNES minimal materi prasyarat sudah dikuasai oleh tutor dan kalau materi tersebut baru serta rumit maka guru hendaknya memberikan matrikulasi terlebih dahulu kepada tutor sebelum pertemuan atau sebagai alternatif dalam kegiatan remedial dengan tutor sebaya.

Kosasih, E. (2014). Strategi Belajar dan Pembelajaran (Implementasi Kurikulum 2013). Bandung. Yrama Widya.

Melati, A. (2015) Pengembangan Modul Praktikum Astrofisika Seri Alat Solarscope Berbasis Integrasi Interkoneksi. Indonesian Journal of Applied Physics, Vol 5, No 1.

Mujiarso, J. (2014). Peningkatan Aktivitas Siswa Melalui Pendekatan Matematika Realistik Pada Materi Kesebangunan di Kelas IX B SMP Negeri 1 Samalantan. Jurnal Pendidikan Matematika dan IPA, Vol 5, No 1, 1-10.

Permendikbud Peraturan Pemerintah Pendidikan dan Kebudayaan. (2013). Kerangka Dasar dan Struktur Kurikulum Sekolah Menengah Atas/Madrasah Aliyah. Jakarta. Kemdikbud.

Siregar .E \& Nara.H. (2010). Teori Belajar dan Pembelajaran. Bogor. Ghalia Indonesia.

Soemarmo, U \& Hendriana, $\mathrm{H}$. (2014). Penilaian Pembelajaran Matematika. Bandung. Refika Aditama. 
Penerapan Metode Pembelajaran Tutor Sebaya 11

Sudijono, A. (1995). Pengantar Evaluasi Pendidikan. Jakarta. PT. Raja Grafindo Persada.

Sugiyono. (2014). Metode Penelitian Pendidikan (Pendekatan Kuantitatif, Kualitatif dan $R \& D)$.Bandung.Alfabeta
Suherman E et al. (2003). Strategi Pembelajaran Matematika Kontemporer. Bandung. UPI

Suyadi. (2010). Panduan Penelitian Tindakan Kelas. Yogyakarta. Diva Press.

Uno, H. B \& Mohamad, N. (2011). Belajar dengan Pendekatan PAILKEM. Jakarta. Bumi Aksara. 